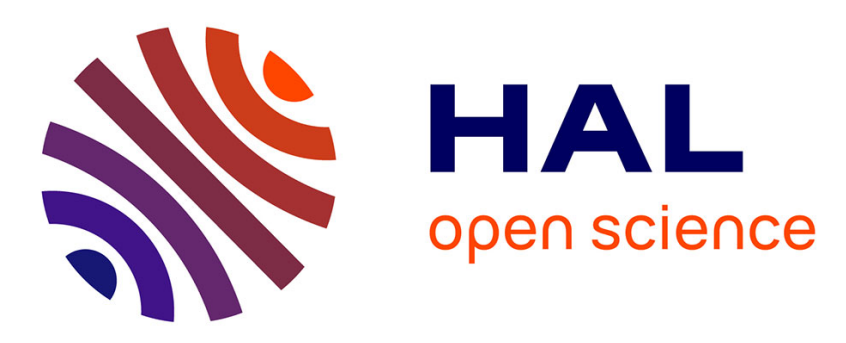

\title{
The Origins of the Higher Education Market: From Theories of Capitalism to an Extrapolation of Clark's Triangle
}

Nicolas Gachon

\section{- To cite this version:}

Nicolas Gachon. The Origins of the Higher Education Market: From Theories of Capitalism to an Extrapolation of Clark's Triangle. The Journal of the World Universities Forum, 2011, 4 (1), pp.31-40. 10.18848/1835-2030/CGP/v04i01/56726 . hal-02818078

\section{HAL Id: hal-02818078 https://hal.science/hal-02818078}

Submitted on 25 Mar 2021

HAL is a multi-disciplinary open access archive for the deposit and dissemination of scientific research documents, whether they are published or not. The documents may come from teaching and research institutions in France or abroad, or from public or private research centers.
L'archive ouverte pluridisciplinaire HAL, est destinée au dépôt et à la diffusion de documents scientifiques de niveau recherche, publiés ou non, émanant des établissements d'enseignement et de recherche français ou étrangers, des laboratoires publics ou privés. 


\title{
The Origins of the Higher Education Market: From Theories of Capitalism to an Extrapolation of Clark's Triangle
}

\author{
Nicolas Gachon \\ Université Paul Valéry Montpellier 3, France
}

Abstract: This paper addresses the problematics of the higher education market in light of the theories and concepts of the emergence and development of capitalism, i.e. as the inevitable offspring of the sprawl of capitalism or, alternatively, as the conjunctural product of globalization. The theoretical existence of pre-capitalistic, pre-global higher education markets, or the absence thereof, are determining factors in tracing continuity vs. discontinuity and in fathoming whether global competition is fueled by opportunity or by necessity. The author looks at the interactions between regional interests, public regulation and market incentives to make the case that competition between higher education "systems" - as opposed to higher education "institutions" - can be very indicative of the real nature of higher education markets.

Keywords: Higher Education Markets, Academic Capitalism, Higher Education Systems

This paper seeks to trace the origins of the higher education market in light of some of the theories of capitalism. Much of the criticism encountered by the increasing adherence to market norms in higher education governance and policy over the past decades has been derived from criticisms of capitalism, of the neoliberal philosophy, and of a seemingly deterministic course of events. Hasty analogies with Charles Darwin's On the Origins of Species would be of very little interest here, although certain issues in the study of the higher education market are indeed consonant with social and political readings of Darwin's biological theories. Darwinian metaphors and concepts of survival, determinism, inevitability, etc. have become explicitly or implicitly present in most reflections on the modern economy but cannot seem to shed significant light on higher education as the principal producer of knowledge in the so-called "knowledge-based" economy. This paper is not interested in the survival of higher education institutions from a Social Darwinian perspective but in higher education systems from a transactional governance and geostrategic perspective. The advent of the higher education market was contemporaneous with the globalization process that started in the 1980s. It is arguably one of its consequences. Analogies with theories of capitalism can be illuminating because the 1980s were precisely the moment in history when the collapse of communism seemed to give reason to those who saw capitalism as a natural and inevitable manifestation of human nature.

In The Origins of Capitalism. A Longer View (2002) Marxist scholar Ellen Meiksins Wood has taken issue with the idea of the so-called "commercialization school" that capitalism is the inevitable product of human nature and of technology and that it appeared naturally as soon as individuals started engaging in commercial, 
profit-seeking activities. Ellen Meiksins Wood distances herself from fellow Marxist scholars because of their implicit acceptance that capitalism is as old as commerce itself when they simply point out that globalization removed the last remaining constraints on its sprawl. Wood's central argument is that a thorough transformation of social relations in 17th and 18th century agrarian England brought about the very conditions that paved the way for capitalism as we know it. Wood regrettably dismisses the importance of the scientific and industrial revolutions to engage into an implicit debate with fellow Marxist scholars on the epistemological vs. teleological interpretation of history. Her views on the origins of capitalism, however, raise crucial questions that are relevant to fathom whether the higher education market was an already existing market that was simply liberalized and boosted by globalization in the last decades of the 20th century or whether it was actually brought about by globalization itself. This is an important step to determine whether competition in higher education is motivated by opportunity of by necessity. In 1983, which coincided with the beginning of the globalization process, in The Higher Education System: Academic Organization in Cross-National Perspective, American scholar Burton Clark produced seminal work on the governance of higher education institutions when he modelized the different types of university governance according to their greater or lesser proximity to one of the three angles of a triangle: the state; academic oligarchies; the market. The three distinct angles are an indication that although the market was indeed gaining importance among such traditional operators as the state and academic oligarchies, higher education itself had not yet grown dependent on or been absorbed by the market. As early as in 1983, Burton Clark could not anticipate the upcoming participation of supranational and intergovernmental structures (the UNESCO, the IMF, the European Union, the World Bank, etc.) which, in later years, were to assume intermediary roles in higher education policy (Gachon, 2009, 28). In 1997, in Academic Capitalism: Politics, Policies, and the Entrepreneurial University, Sheila Slaughter and Larry Leslie studied the impact of "academic capitalism" on academic work and administration and denounced a shift from altruism and public service, i.e. student needs, towards market values, i.e. leveraging resources from student customers. They defined academic capitalism as "any institutional and professional market or marketlike efforts to secure external moneys" (Slaughter and Leslie, 1997, 8) and focused on its impact on academic labor at institutional level, significantly pointing towards the market angle in Clark's Triangle.

This paper makes the case that the higher education market is an intrinsically systemic phenomenon that does not only behave as a conglomeration of its elementary institutional components but that responds primarily to cross-border impulses at systemic sub level. This postulates an extrapolation of Clark's Triangle and raises crucial issues that theories of capitalism can help look at. Were the pervasive changes in academic labor studied in Slaughter and Leslie's Academic Capitalism an inevitable evolution of higher education whose natural development was facilitated by globalization, or were they in reality a modification of social relations that were to lead to the higher education market - which would make them precapitalistic or transitional by nature? 


\section{Theoretical perspectives}

It is virtually beyond any point to ask whether or not the higher education market is capitalistic by nature: it most assuredly is. That said, to study the impact of capitalism on academic labor is not to address the origins of the higher education market, nor to tackle how higher education differs from traditional consumer goods markets. As a matter of fact, such landmark issues as tuition fees or competition between universities did exist long before the advent of the knowledge-based economy and were not generated by it. More recent features of the higher education are also very much distinct from traditional capitalistic models: international student flows, for example, a prime concern in higher education policy today, cannot possibly be envisioned as mere tangible commodities. The transition and distinction from a supposedly precapitalistic model is at stake here. Classical theories of the advent of capitalism view the transition in quantitative terms, as an increase in productivity and exchanges that was made possible by increased specialization in the production process and by constant improvement of the means of production, not by qualitative changes or by significant modifications in social relations. Higher education seems to be intrinsically at odds with the theory of quantitative "accumulation" so central to theories of capitalism, whether it be in either of the opposing views of Adam Smith, whose "accumulation of stock", in Book II of The Wealth of Nations (1776), was the result of success in the marketplace, or of Karl Marx, whose primeval accumulation ("ursprüngliche Akkumulation") marked the starting point, not the result of capitalism in Das Kapital (1867). If accumulation does not appear to be the right lens to capture the beginnings of the higher education market from a capitalistic angle, the idea that a transition towards a higher education market occurred at some point in the advent of globalization remains valid on its own terms. The hypothesis of a supposedly precapitalistic model that may have prefigured the higher education market is just as workable as the traditional hypothesis that a society "with markets" predated the market society, arguably even more so because of the non-tangible nonindustrial nature of knowledge.

Socialist economic historian Karl Polanyi made the case that mechanisms or modes of integration other than the market, namely reciprocity and redistribution, could be at work in an economy and had indeed been in primitive societies (Polanyi et al., 1957, 250). Polanyi's Trade and Market in the Early Empires provides an interesting frame to look at precapitalistic markets where competition may not have been a primary motive, even in the context of profit-making commercial transactions. Polanyi's perspectives can be useful to look at the evolution of higher education in the past decades. Colleges and universities have existed for centuries and, as institutions, have always made every effort to attract the best possible faculty with a view to their own academic needs and to their own local, national and international reputations. Higher education institutions have always been engaged in various forms of communications, exchanges and collaborations because the confronting of ideas has always constituted the only possible way to foster knowledge and validate the quality of research. In other words, some form of knowledge and technology transfers have always existed. This is coherent with Clark's Triangle which, in 1983, saw the market as only one in three governance models, together with the state and academic 
oligarchies. However, the transition or rupture between a system based on simple transactions between higher education institutions and today's allegedly selfregulated higher education market still has to be accounted for. What caused the center of gravity in Burton Clark's geometrical model to move irremediably towards the market angle? As already mentioned, the floodgates for the global higher education market were not opened by a sudden significant accumulation of capital. Two major factors were actually at work. The first was the tremendous development of information technology, arguably "to the era of globalization what the steam engine was to the industrial age" (Gachon, 2009, 25). Information technology triggered an unprecedented multiplication and massification of communications and exchanges. The links and relationships that had always existed between higher education institutions now became demultiplied and they suddenly gained global, no longer only local or national significance. Higher education marketplaces became intertwined to the point of forming a global higher education market. Critics of globalization could argue that this specific development is in fact no other than what American sociologist Immanuel Wallerstein has described as the "world systems theory" and which sees the world as a mechanism that redistributes resources from the periphery to the core, i.e. from the developing world to the industrialized world (Wallerstein, 1980). Although it effectively makes the case that the global higher education market puts developing countries at a disadvantage with regard to their university systems (Svenson, 2010, 87), an indication that the higher education market is an imperative rather than an opportunity at least for developing countries, Wallerstein's The Modern World-System II: Mercantilism and the Consolidation of the European World-Economy, 1600-1750 still relies on the concept of accumulation in a way that can only partially help address the global self-regulated dimension of the higher education market. The other factor that generated the global higher education market was the political environment of economic development in a context of massified communications and exchanges. A number of Marxist theorists of capitalism, in particular theories of a rift between politics and economics, provide conceptual frameworks that may be applied to higher education in the age of globalization. In Lineages of the Absolutist State (1974), Perry Anderson has argued that absolute monarchies were in fact a reconstruction of the feudal state that actually defended the interests of ruling class by lifting power above the individual seigneurial units of feudalism which combined both political and economic power. The centralization of political power under the absolute state caused the rupture with local economic activity that provided the necessary autonomy for the sprawl of capitalism. Perry Anderson is among the Marxist scholars Ellen Meiksins Wood criticizes for indirectly validating the notion that capitalism was inevitable and that it came about the as soon as political obstacles were removed (Wood, 2002).

The global higher education market is composed of national university systems. Although critics of globalization will denounce the dark hand of supranationalism, there is no "absolute" "political" power that intentionally defends the power of the world's ruling classes. An in-verted version of Anderson's model, however, is theoretically defendable. The rise of information technology and the multiplication of cross-border exchanges created a massive global network that placed the higher education market above the constraints of national policies, making 
it largely self-regulated - for better or for worse. Most theories of capitalism rely on the notion of an economic continuum that was at some point relieved from the fragmented and fragmenting constraints of political control. Things were significantly different in the field of higher education: a political continuum of public regulation has always been at work due, if only, to the highly strategic dimension of higher education and research for nation-states (Gachon, 2009).

\section{Transitional Perspectives}

It can be argued, from Ellen Meiksins Wood's standpoint, that globalization is in fact no other than capitalism itself having reached modernity (McChesney et al., 1998, 48), which raises a central issue as advocates of capitalism usually insist that capitalism means opportunity and prosperity and that communism means hopelessness and economic stagnation. How does the higher education market fit in either of these analogies? Anti-capitalists will argue that capitalism is system in which all economic actors have grown entirely dependent on the market and that it cannot be viewed as meaning opportunity, all economic actors being subjected to market imperatives. From this perspective, the market arguably turned into a capitalist system the moment it precisely became an imperative. To return to a parallel between the industrial age and the age of globalization, the rise of the Standard Oil Company and the tactics it used to push small producers out of business (certainly an imperative, not an opportunity for them) and to destroy most of its competition in the 1870s does indeed reverberate with the rise of a company like Microsoft in our time. But the fact that the Sherman Antitrust Act was used to break the both Standard Oil Company and Microsoft in separate units also testifies to a continuum in the state's will to regulate market mechanisms (Gachon, 2009, 25). At the foundation of the anti-capitalist argument lies Marx's "commodity fetishism" (Das Kapital, 1867) and the claim that capitalism transforms social relationships into objective relationships between commodities or money. However, "commodity fetishism" cannot apply to the higher education market along the same lines as knowledge, education, even academic "labor" at large, can hardly be regarded as commodities. Profit-making was initially at the core of the rise of capitalism but it was not initially the primary motive behind the development of higher education.

This is important to understand how the humanities and the experimental sciences have evolved over the years. The humanities usually resent the emergence of market norms in higher education more than the empirical natural sciences do because the humanities study the human condition, using methods that are analytical, critical or speculative and that have little commercial value although they are arguably the oldest and noblest component of higher education. For the humanities, therefore, the market is more often than not perceived as an imperative rather than as an opportunity, one that tends to downgrade their status in the higher education institutions where entrepreneurial methods are gaining preeminence. The experimental sciences can have direct market value, through patents or through the transfer of knowledge to industry, and can have a more opportunistic approach the higher education market. However, they are faced with the same issues, as testified by the tensions between fundamental research, which has little immediate market 
value but does have long-term strategic interest, and applied research, which has short-term market value but nonetheless relies on fundamental research. The market is more of an opportunity, therefore, at least in the short term, for applied research than it is for fundamental research. These mechanisms are not as global and selfregulated as their critics often argue. Again, there is no absolute global authority, political or economic: the global higher education market, as a matter of fact, needs nation-states, to secure property rights, for example, as in the case of patents. Patents secure the exclusive right, granted by a national government, to benefit from an invention and are essential to the knowledge-based economy. Technology transfer is indeed profit-seeking and capitalistic by nature, but it happens to operate in sensitively different ways when research is conducted in private research institutions and when it is conducted in non-profit institutions like universities, i.e. institutions that do not distribute their surplus funds to owners or shareholders but that reinvest them to pursue their own missions and goals. Because of their intermediary status between their economic imperatives, their public service missions and their tremendous strategic value for the attractivity of nations, higher education institutions operate within politically oriented systems, national or supranational, in the global higher education market. In the case of the knowledge-based economy, the so-called rupture between the economic and political spheres is at best partial.

The "global" quality of the higher education market is characterized by multiple, multi-directional, cross-border interactions which have gained strategic market value in recent years. Student mobility, one among several landmark phenomena, formerly known as "foreign student exchange", has been relabeled "international student mobility" to better account for the demultiplication of multidirectional flows to and from higher education institutions. The offer has increased, allowing students to pick and choose from a variety of international programs. The demand for students has also increased as students now represent a colossal source of revenue, contributing no less than $\$ 17.6$ billion to the U.S. economy in 2008-2009 (NAFSA, 2008-2009). There is more than just talents and ideas, critics of the neoliberal philosophy will argue, claiming that students have been turned into commodities traded on the free market. The issue of tuition fees, however, is actually a national and institutional issue that was not generated by the global higher education market. Tuition fees at universities in the United States have always been considerably high by comparison with the tuition fees in a system like France where tuition costs are subsidized by tax-payers for all students, including international students. Yet international student mobility flaws are not converging towards France simply because tuition fees at French universities are comparatively low. Tuition fees constitute a factor and an indicator among other factors and indicators. Market-related excesses have of course occurred, such as the emergence in a number of countries of for-profit non-accredited higher education institutions, but, even if that case, the failure to obtain accreditation reveals that the quality of the overall system remains largely safe-guarded by the academic community. The poor quality of many international programs apparently more preoccupied by their international packaging than by their actual academic contents can also be regarded as regrettable market-related excess, a phenomenon incidentally encouraged by the blind reliance on student mobility figures to assess the internationalization of higher 
education (Gachon, 2008). The systematic reliance on student mobility figures is typically a political tool used by nation-states and by their agencies, which, again, shows that no systemic dismantling has yet actually taken place in the context of a global higher education market. Higher education systems pushing their own geostrategic interests are currently the moving force behind the higher education market.

\section{Transnational perspectives}

There is no uniformization of the policies of higher education systems or of their relationship with the market. The Australian higher education system, for example, evolved towards a profit-oriented approach of international mobility when the government decided to regard higher education as an export industry and created the Overseas Student Charge in the 1980s. At the other end of the spectrum, a number of models view higher education through the prism of development aid and rely on supranational operators like UNESCO or Francophonie, or on national agencies like the Canadian International Development Agency. Europe, an-other supranational structure, is a highly political model although it was initially the product of a free trade area. The European Higher Education Area, one of the core objectives of the Bologna process, was meant to create more comparable, compatible and coherent systems of higher education in Europe. Yet the colossal success of the Erasmus mobility program is first and foremost the political achievement of a noble cause: the indispensable rapprochement of the youths of the different member states to lay the foundations of a common future. Erasmus has facilitated mobilities for over two million European students since it was launched, which is assuredly a political feat but less of an academic achievement as the program cannot compete with high quality international programs such as double or joint degrees (which European universities also offer in great numbers). There is no uniformization of higher education policies but standardization is absolutely at work to make the different systems compatible, which was another key objective behind the European Higher Education Area. The European Bachelor-Master-Doctorate curriculum not only made European systems more compatible with one another, it made them more compatible with the American higher education system to facilitate transactions, exchanges and transfers. Public regulation with transnational perspectives is therefore very much at work.

The not-for-profit dimension of higher education is theoretically ideal as long as revenues can indeed be reinvested by institutions to pursue their own missions and goals. From this perspective, universities can theoretically compete for revenues in a global higher education market that can indeed be regarded as an opportunity. Yet the competition for revenues is not the initial motive of higher education; it has become a necessity for institutions to be able to pursue their own missions and goals with research becoming more and more costly in the experimental sciences. Technology transfer has become vital and inequality is the rule, as implicitly stipulated by Allan E. Goodman, President and Chief Executive Officer of the Institute of International Education, in his 2008 testimony before the United States House of Representatives Subcommittee on Research and Science Education: 
American campuses and graduate departments increasingly rely on international students to provide valued research or assistance in teaching. Today, more than one third of U.S. engineering and computer science faculty are foreign-born, many of whom came to the U.S. first as an international student. Nearly $50 \%$ of the U.S. doctorates awarded in engineering and computer science go to international students and many foreign students are serving as teaching or research assistants especially in Science and Technology graduate departments to which American students are simply not applying. These students and scholars further contribute through patent applications and innovation [...]. [M]ore than 50\% of Ph.D. engineers working in the U.S. are foreign born. $45 \%$ of math and computer scientists, as well as life scientists and physicists working in the U.S. are foreignborn. More than one-third of Nobel Laureates from the United States are immigrants. Over $60 \%$ of finalists in the 2004 Intel Science Talent Search, which are the top high school science students in America, were the children of immigrants with $20 \%$ of those parents coming to the U.S. as international students. (Goodman, 2008)

This is highly reminiscent of Immanuel Wallerstein's "world systems theory" which sees the world as a mechanism that redistributes resources from the periphery to the core, from the developing world to the industrialized world (Wallerstein, 1980). However, Marxist criticisms of capitalism as an imperative rather than an opportunity can hardly apply to the global higher education market. In the present case, i.e. the percentage of foreign-born re-searchers and engineers in the United States, the truth is that the global higher education market is in fact both an opportunity and imperative for the industrialized world, because of competition between industrialized countries or systems. That competition can be fierce and technical: universities in North America, for example, tend to use the one-year gap between the three-year European Bachelor's degrees and their own four-year Bachelor's degrees to send fourth-year undergraduate students to Europe and to host fourth-year, i.e. graduate, European students who will be involved in research projects and may well be enticed to stay longer if not permanently in North America. Whether this is a problem or not is open for discussion as industrialized countries can design policies to support and defend their own higher education systems. The situation is more preoccupying in the developing world where the so-called "brain drain" implies that the higher education market is in fact neither an opportunity nor an imperative, because return mechanisms do not operate and because many countries simply do not have access to the global market. This has serious repercussions because universities have local, not only national and international imperatives. Universities in the developing world are stripped of both the necessity and the opportunity to meet with immediate local imperatives, development included, because of the ethnocentric, brain draining, periphery-to-center (Wallerstein, 1980) operations of the higher education market.

\section{Conclusion}

To answer the questions raised in the opening lines of this paper, the higher education market cannot be regarded as an "inevitable" evolution of higher education whose natural development was simply facilitated by globalization. Such an argument 
would almost make of globalization itself an "inevitable" evolution of international activity. The sudden advent of a virtually instantaneous network of communications and exchanges at global level altered the traditional mechanisms that had so far ruled the political and economic spheres at national level, in a way that is reminiscent of Perry Anderson's argument that it was the centralization of political power under the absolute state that caused the rupture with local economic activity that provided the necessary autonomy for the sprawl of capitalism (Anderson, 1974). However, due to the very specific nature of knowledge, the basic tenets of Marxist theories of capitalism, primitive accumulation and commodity fetishism, simply cannot apply to the higher education market. The pervasive changes in academic labor studied in Slaughter and Leslie's Academic Capitalism (1997) were therefore no precapitalistic modifications of social relations, such as those described in Ellen Meiksins Wood's Origins of Capitalism (2002). Yet they were certainly not an inevitable evolution either, because the core missions of higher education were not originally adjusted to market norms. This is consonant with Karl Polanyi's argument that mechanisms or modes of integration other than the market, namely reciprocity and redistribution could be at work in an economy and were indeed in primitive societies (Polanyi et al., 1957, 250). Finally, this paper has suggested that an extrapolation Burton Clark's Triangle (1983) would be useful to look at higher education. The proposed model is one that focuses less on the sources of governance (the state; academic oligarchies; the market) and more on transactional governance to account for the new models that have emerged in recent years and that have placed higher education institutions in intermediary positions between their economic imperatives, their public service missions, and their systemic value.

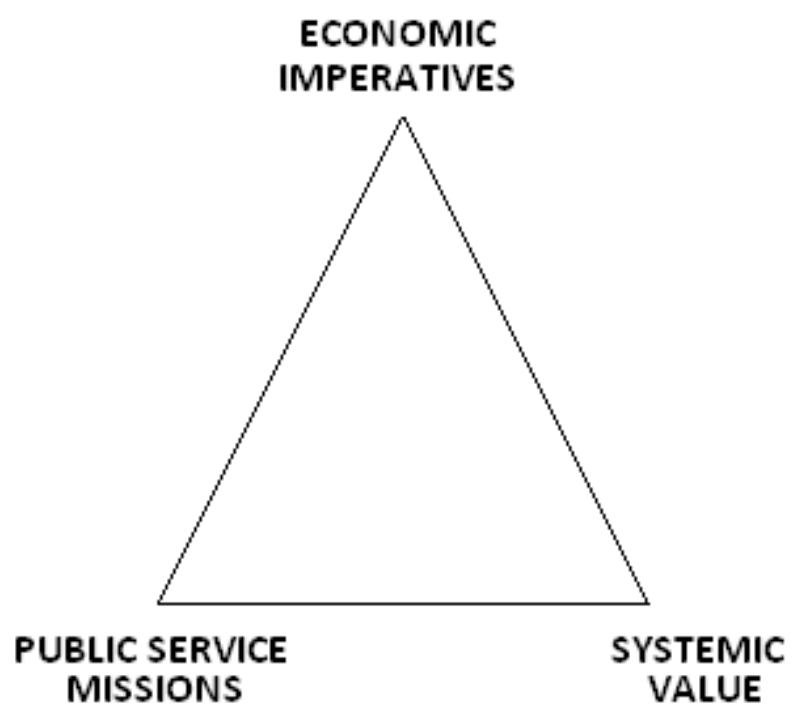

Figure 1: Extrapolation of Clark's Triangle 


\section{References}

Anderson, Perry. Lineages of the Absolutist State. New York: Routledge, 1974.

Clark, Burton R. The Higher Education System: Academic Organization in CrossNational Perspective. Berkeley: University of California Press, 1983.

Gachon, Nicolas. "Reconsidering student mobility per se as a tool for internationalizing higher education in the knowledge-based economy." International Conference on Education, Research and Innovation (November 2008). Published on CD-ROM (ISBN: 978-84-612-5367-8).

Gachon, Nicolas. "Political Continuum and the Adjustment of Higher Education to Market Norms." Journal of the World Universities Forum, vol. 2, 3 (2009), pp. 2234 .

Goodman, Allen E. Hearing on: "Status of Visas and Other Policies for Foreign Students and Scholars." U.S. House of Representatives Subcommittee on Research and Science Education, Committee on Science and Technology (February 7, 2008), http://science.house.gov/publications/hearings_markups_details.aspx?NewsID=206 (retrieved May 11, 2010).

McChesney, Robert W., Wood, Ellen Meiskins and John B. Foster (eds.). Capitalism and the Information Age. New York: Monthly Review Press, 1998.

NAFSA. "International Students Contribute \$17.6 Billion to U.S. Economy." 20082009 Economic Impact Statements, http://www.nafsa.org/publicpolicy/default.aspx?id=17174 (retrieved May 15, 2009).

Polanyi, Karl, Arensberg, and Harry W. Pearson Polanyi (eds). Trade and Market in the Early Empires. New York: The Free Press, 1957.

Slaughter, Sheila and Larry Leslie. Academic Capitalism: Politics, Policies, and the Entrepreneurial University. Baltimore: Johns Hopkins University Press, 1997.

Svenson, Nannette. "Analyzing the Effects of Globalization on University Systems in the Developing World: A Conceptual Framework Applied to the Case of the Republic of Panama." Journal of the World Universities Forum, vol. 3, 1 (2010), pp. 75-90.

Wallerstein, Immanuel. The Modern World-System II: Mercantilism and the Consolidation of the European World-Economy, 1600-1750. New York: Academic Press, 1980.

Wood, Ellen Meiksins. "From Opportunity to Imperative: The History of the Market." Monthly Review (July-August 1994), pp. 14-40.

Wood, Ellen Meiksins. The Origins of Capitalism. A Longer View. New York, London: Verso Books, 2002. 